Nahda Shehada 'Negotiating Custody Rights in Islamic Family Law' in Permutations of Order edited by Thomas Kirsch and Bertram Turner, Aldershot/Burlington: Ashgate, 2009.

\title{
Negotiating Custody Rights in Islamic Family Law
}

\section{Introduction}

The following examines the application of Islamic family law with regard to custody and custody rights in the Gaza city shari ${ }^{-} a$ courts. ${ }^{1}$ Four objectives are pursued in the paper. First, it identifies areas of gender asymmetry in the legal code, which distinguishes female-oriented physical care of the ward (badana) from male-oriented guardianship (wilaya). Second, while examining the strategies adopted by men and women in claiming (or refraining from claiming) custody rights, the paper identifies areas of tension between the textually prescribed custody rights and their highly differentiated social construction. Thirdly, in fulfilling these objectives, it demonstrates the ways in which judges deal with various aspects of custody, and how, in the process, a knowledge of social norms overshadows the text; it will argue that today's judges are still loyal to the heritage of Islamic jurisprudence, which asserts the concepts of fairness, consideration of the context, and protection of the weak. Finally, the conduct of judges is elaborated with reference to the notion of $\ddot{j}$ tihäd (independent reasoning) in the contemporary application of Islamic family law. An illustrative case is presented to argue these points.

\section{Theoretical underpinning}

The paper draws on the theoretical insights of Moore (1978, 2000, and 2005) who has been acknowledged for changing the paradigm of law and society in her seminal work, Law as Process (1978). In her book, Moore examines the duality of order and change in the social working of law. Order (law) always exists, but it never fully prevails. It leaves gaps of indeterminacy, which make adjustment, that is, change, necessary. The interplay between order and change provides people with sufficient space to adjust the law to meet a variety of objectives.

Custody, the focus of this study, is subject not only to the order of law, but also to the particular matrix of social relations within which individuals operate. In this context, it is important to emphasize the fact that unlike legislation, which purports clarity and universality, social relations are full of ambiguities, inconsistencies, and discontinuities (Moore 2000). The temporality of social relations is essential, which entails that indeterminacy exists as a pervasive quality of social and cultural order. Thus, people's behavior might be interpreted in two ways. On the one hand, they try their best to control their lives by furthering the rule of order and working to fix and crystallize social reality. Such attempts at 'social regularizations' would ultimately produce what Moore calls 'conscious models', which are meant to organize and systematize people's 'customs and symbols and rituals and categories and seek to make them durable' (Moore 2000:50). This fixed model has its own merits; it allows people to live in relative stability and predictability, thus enabling them to plan their lives and interact with others on the basis of reasonable expectations of behavior. However, when the 'conscious model' becomes constraining, people tend to search for gaps in the model to counter its curtailments. They may even generate such gaps to accommodate new circumstances that have not been foreseen by the

\footnotetext{
${ }^{1}$ The chapter will not touch upon the changes that have been taking place in the Palestinian society since the withdrawal of Israeli troops from Gaza (September 2005) nor analyze the impact of the Hamas victory (January 2006) on the operation of shari ' $a$ courts. This does not underrate the importance of the ongoing process of spatial and social fragmentation within Palestinian society since the eruption of the second intifada (2000).
} 
model,and thus engage in 'processes of adjustment'. The ambiguous area between the pervious order and the new adjustment is the area in which indeterminacies occur. Moreover, Moore's framework does not regard the determinate and indeterminate as fixed states, but rather as everchanging processes. What is fixed is only the continuous renewal. If 'situational adjustment' is adopted, repeated, and becomes a pattern in people's lives, then it is likely to be part of processes of regularization; this implies that each process 'contains within itself the possibility of becoming its schematic opposite' (Moore 2000:51).

In the shari' $a$ court, litigants often search for such gaps of indeterminacy, ambiguity, or uncertainty in the interplay of codified law, social customs, and the multi-referential framework of judges, in order to find space to express and materialize their needs and interests. ${ }^{2}$ In the course of their attempts, litigants often maneuver and manipulate these structures and sometimes succeed in turning them to their benefit.

Moore also stresses the importance of investigating the context within which the law operates and thus within which familial disputes are resolved. The source of the law used in dispute settlement does not matter, analytically, as much as the context within which the process of 'amalgamation' takes place.

In the particular context of Gaza, judges and litigants operate in 'multiplex relationships'. These relationships 'endure through the lives of individuals and even generations' (Gluckman 1955:20-1). Each relationship is part of a complex network of multiple bonds. The implications of any dispute between spouses reach far beyond their 'private' life in the sense that the social relations between their respective families are strongly involved. What makes the picture more complicated is the fact that these familial relationships (between the spouses' families) are also part of the larger social setting of Gaza, in which the boundaries between kinship, politics, and economy are often blurred. The effect of any disruption in one aspect of these multiplex relationships causes equivalent or greater disruption throughout a series of other relationships. Therefore, it is often observed that the judges not only investigate the particular dispute beforehand, but also expand their investigations to include other ties that embrace many interests, and which may have further implications in the future.

Furthermore, within the context of Islamic family law, the duality of customary practice and codified law raises the question of how we should define law; or indeed what law is. Moore's concept of a 'semi-autonomous' social field, which deconstructs the single legal field into several arenas, was a revelation for sociologists interested in law (see Chanock 2000: xi). Moore points out that we should not apply the term law only to those binding rules enforced by governments or states. For sociologists, law is better seen as a social phenomenon that indicates 'every form of rule pertaining to an organized group in any society' (Moore 2000: 18). In her view, any form of rule that entails authority, an intention of universal application, obligation, and sanction should be deemed to be law (see also Pospisil 1971). The dichotomy between codified law and 'other' laws does not in fact reflect social reality. This applies to both industrial and less-developed societies. In the former, as Moore observes, although a presumed 'rational' state law is applied, it is smoothly sidelined on some occasions. Thus, in both settings, formal laws can work only partially; they have never controlled (and perhaps never will be able to control) every social activity.

\footnotetext{
2 The first attempt to codify the $\operatorname{sharl~}^{\prime} a$ in Islamic history, as Botiveau (1997) points out, took place as early as 1534. Three centuries later, the Ottomans introduced commercial and civil laws in a process known as Tanzīmāt through the adoption of codification based on the European model. Later, the majalla appeared (1869-76) as a compilation of Hanafi civil law regulations (Welchman 2000). At the beginning of the twentieth century, ten years after the restoration of the 1908 constitution, the Ottomans introduced the first personal status code of its kind, known as 'The Ottoman Law for Family Rights', for the application in the shari' 'a courts.
} 
In Palestine, customary practice, as Welchman (2000: 6) contends, 'constitutes a stronger controlling force than the [family] "law". Customary practices are customs defined by anthropologists as describing 'patterns of behavior of a particular group' (Gluckman 1955:236), or simply put, the primary forms of maintaining social harmony. They manifest particular ethical values of certain groups, but are nonetheless often based on hierarchical distribution of power and resources. Rights and obligations in the context of applied Islamic family law thus become subject to both. This is evident when considering the historical development of Islamic family law, which shows that it has not been entirely imposed from above, but has rather arisen from below, from communities that practiced rights and obligations, thus leading to their recognition (see Hallaq 1984; 1997; Gerber 1994; 1999; Esposito 1982).

When applying Islamic family law, judges not only use customary codes but also other 'Islamically informed legal concepts'. Goals such as the public interest (maslaha), equity (istihsān), protecting vulnerable members of society, and similar matters serve to ensure that the litigants receive what they identify as 'justice'. Unlike the codified law, these are unwritten codes and require the discretion of the qädì to be realized. Sometimes, in its application, codified law may come into conflict with the judges' objective of providing 'justice'. When such a paradox arises, the judge works it out by employing the 'legal concepts'. Unlike law, which is supposed to be clear, particular, and decisive, 'legal concepts' are flexible, permeable, unspecific, unwritten, and used by the judges to manipulate the code and surmount situations in which paradoxes between the written code and social reality are inevitable (see Gluckman 1955). Hence, the judges' flexibility is generated from this multiplicity of references, or combinations of rule-binding law and imprecise principles, which in fact provide the grounds for the application to be flexible.

\section{The Legal Text}

Having introduced the theoretical framework of this study, let us now move to the legal text to review its gendered nature. The shari' $a$ courts in the Gaza Strip rely on two legal references for the application of family law: the Law of Family Rights (LFR) of 1954 and the Book of Personal Status Rulings According to the School of Abū Hanīfa compiled by Qadrī Pāshā (BPSR) of 1875. The LFR provides fewer details than the BPSR on how judges should treat custody cases. This makes judges more reliant on the BPSR for their rulings. In organizing custody rights, the BPSR reflects a particular world-view regarding the status of the person: gender, age, lineage, religion, and morality are all important, but gender is the fundamental axis along which custody rights and responsibilities are distributed. The BPSR divides custody rights into wilaya (guardianship, authority, decision-making, and maintenance), which is exclusively the domain of the father or male agnates, and badana (care, feeding, clothing, and bodily hygiene), which is assigned to mothers or female relatives (see Welchman 1999; Layish 1975). This hierarchical division of custody into different domains is consistent with the gendered philosophy of law, which identifies fathers as the final decision-makers while mothers may or may not be viewed as care providers.

Thus, the concepts of wilàya and badana cannot be conveyed accurately using the blanket term 'custody'. The most salient feature of hadana is that it does not entail major decision-making regarding the child. Its Arabic root hadana means to hold in one's arms, to embrace and to place on the lap. The Lisan al-'Arab gives a broader definition of hadana: 'to nurse, to bring up or to raise a child' (quoted in Zahraa and Malek 1998: 156). According to Samara (1989: 368), hadana means 'taking physical care of the child who is still unable to do so by itself. The one who has the right to do this is the bädin (the carer)'. In contrast, wilayy refers to notions of authority and decision-making. It is divided into two aspects: guardianship of a person and guardianship of property (wilàya 'ala al-nafs wa wilaya 'ala al-mä). The guardian (wali) has the right to exercise authority over both the person and the property of the ward. 
The division of custody into hadana and wilayya is distinctly gendered. While mothers cannot transgress this gender boundary, men may cross the limits established by the law, as we shall see later in this section. The BPSR devotes one full chapter of 14 articles to custody issues while the LFR has only one such article. Article 118 of the LFR specifies one matter of importance: permission is given to the qädi to allow mothers to extend the period of their hadana over boys until they reach the age of nine and over girls until they reach the age of eleven, if 'the qàdì believes that [the child's] interests will be served by that'. In this way, the LFR stretches the time limit of mothers' hadana by two years beyond the period previously stipulated by article 391 of the BPSR.

\section{Litigating Custody}

The above review was made not only for its relevance to the sections below, but also to contrast the ideological construction of law with its highly differentiated applications. Let us now turn to the court to see how the law is applied in concrete situations, how rights are claimed and negotiated. How does the social context within which litigants file claims influence the process of litigation and ruling? The following ethnographic material was collected during 14 months of fieldwork in 2001-2003 and is grounded in the observation of the legal and social universe of shari' $a$ courts. $^{3}$

In litigation over custody, the legal text operates in a social context in which various complex webs of relations determine the outcome of the case. As in all family disputes, custody cases do not reach the court unless all other avenues for resolving the conflict have failed, indicating the degree of disagreement and bitterness between the spouses and their respective networks. As has been noted in a variety of studies (legal and anthropological), certain factors discourage individuals from going to court; financial cost, a lack of information or time, and the

\footnotetext{
${ }^{3}$ I conducted this research between 2001 and 2003 in the Gaza Strip, one of the two sections that make up the Palestinian territories occupied by Israeli military forces in 1967. The occupation has made travel both extremely difficult and hazardous, especially due to multiple checkpoints and frequent Israeli raids on Palestinian towns and cities. Initially, my intension was to explore the strategies developed by the Palestinian women's movement to achieve family law reform. But Israeli-imposed restrictions on movements hindered this undertaking. I decided to make only a few visits to the shari ' $a$ courts to explore the possibilities to save my research. The first visits fascinated me to such an extent that I could sit for hours just listening to the daily encounters between the judges and litigants. Gradually, I grasped the necessity of understanding family law dynamics before considering reform. I obtained permission from the chief judge to carry out my research in the court and started attending the hearings regularly. To try and blend in, I began wearing a headscarf and sat in the section reserved for the litigants' family and friends. The change in the research focus was a blessing, for it was only then that I understood the difference between the making of law from above and the dynamics of its remaking from below. I was struck by the discrepancy between the dominant public discourse on Islamic family law and its practical, less ideologically charged application. The encounters with the judges, lawyers, and female litigants, as well as the process of continuous negotiation and bargaining inside the courtroom, led me to re-examine my biases and assumptions. After a few weeks, it became obvious to me that the social construction of law differs significantly from the law as published in books.

I was particularly struck by the flexibility of the judges; they play a significant role in protecting women from abuse by their male relatives. Judges show sympathy and consideration; they do not hesitate to reprimand men for treating their wives badly, citing Quranic verses that call for women to be treated with respect and compassion. After deciding to continue to explore the application of Islamic family law in its entirety, I combined a partially open-ended ethnographic approach with semi-structured interviews with judges, lawyers, litigants, and court personnel. Litigants' life-histories and those of relevant other actors were generated in order to gain more insight into the backgrounds and positions of those concerned. In particular, while processing the cases, I constructed some individual life-histories, recorded ideological positions, investigated occupational or economic circumstances, composed the dispute history, and gathered information on norms relating to specific actions. The qualitative data were combined with an analysis of the text of family law and its various interpretations. This paper presents only parts of the data and analysis generated in the course of the research trip. The full research is published in Shehada 2005.
} 
shame attached to revealing one's own private life to public institutions are only some of the factors that account for such patterns. In matters related to custody, the socio-economic circumstances constitute crucial elements in deciding the fate of the children since custody involves not only physical care (by the mother's side of the family), but also financial responsibility (on the father's side of the family). Some fathers (or agnates) default on the children's nafaqa because of their (alleged or actual) financial difficulties. Instead, they offer to take the children to be raised in their homes, which they believe to be the more economically efficient option. As one claimant said: 'My children will not cost me more than what I currently spend; they will eat from my dish and sleep on my mattress.'

The picture is further complicated when a hadana case concerns widows; they become subject to pressure emanating from different sides. If widows aspire to keep their children with them, they have to maintain a positive relationship with their in-laws, for the law alone does not guarantee them hadana. Various court cases indicate that some in-laws file suit against mothers just because of their embittered relations. If the mothers are young, with a few children, their own families also exert pressure on them to hand over the children to their in-laws, since children would curtail the mother's prospects of remarriage. Given their economic dependency on their families, widowed women show little resistance. The rationale behind this behavior is that sooner or later the mother will be legally or 'socially' forced to give up her children (see also Moors 1995). Moreover, keeping the children with the mother would, in most cases, mean additional expense for her family. And due to the conformity between the agnatic responsibility set by Islamic family law and people's perceptions regarding the distribution of rights and duties between agnates and the mothers' relatives, her family would be reluctant to cover the expenses of a child belonging to 'another' family.

Unlike the formulation of the code, in which gender is the most informative characteristic, the actions of judges are based on principles related to serving the best interests of the child, given the socio-economic context in which litigants operate. Sometimes they conclude the case at the expense of fathers' legal rights, sometimes at the expense of mothers' legal rights, but in all cases, the eyes of the magistrate are focused on providing the child with the 'particular justice' that s/he deserves.

The following case illustrates how the deputy qādì al-qudāh had to intervene personally when a divorced woman was faced with two difficult choices: to give up her children or to renounce their maintenance rights. ${ }^{4}$ The qädì al-qudāh's advice to her, which was situationally embedded and socially informed, helped her to keep both, the children and their maintenance. Although she had to compromise over parts of their financial rights, the overall result was in her favor.

Adāla, a 35-year-old primary school teacher, had recently been divorced from Ziyād when I met her. He had left her with ten children, the eldest being a 15-year-old girl and the youngest a three-year-old boy. Ziyād married another woman who also worked as a school teacher. Adāla teaches at an UNRWA ${ }^{5}$ school, which pays a higher salary than government schools. After the divorce, she filed a nafaqa suit for her children and won it. Ziyād had to pay JD 25 (Jordanian dinars) for each child, the total amounting to more than $60 \%$ of his salary. The court had the authority to deduct the nafaqa directly, since he was a government employee. After a few months, Ziyād tried to escape this financial burden by filing a case for custody over the two eldest girls. His aim was to put pressure on Adāla to stop claiming the nafaqa. Although Samāhir and Ilhām were aged 15 years and 14 years, which meant they could legally be placed in their father's custody, Adāla was worried that her daughters would become servants in a household where the wife was not their mother. Adāla did not want to give up her daughters, nor did she accept the

\footnotetext{
${ }_{5}^{4} q \bar{a} d \bar{l}$ al-qudāh could be translated as "chief judge".

${ }^{5}$ United Nation Relief and Work Agency.
} 
father's dependence on her to finance her children. In order to keep the children as well as receive the nafaqa, she went through many difficulties.

First, she had to prove that the father was ineligible to be a custodian. She hired Khālid al-Tayyib, who is reputed to be one of the best lawyers in Gaza, who acted on behalf of the eldest daughters and chose a strategy based on an incident in which the father had beaten his daughter in the street and torn off her headscarf. Khālid al-Tayyib brought witnesses to prove the veracity of the incident. He told the court: 'The father is not eligible to be a custodian because he has beaten his daughter twice in the street. The most disgraceful act was that he took off her headscarf and uncovered his daughter's hair. Samāhir [the daughter] is a mature Muslim woman and it is forbidden for her hair to be seen in public ['awra]. That was not the act of a protective father. Men have to provide the female relatives who are in their custody with the protection that Allah has asked us to afford them. Failing to do so means that the father is not eligible to be a protector and should therefore not be allowed to get his daughter.'

Ziyād's lawyer interpreted the incident differently. He told the court: 'My client's daughter is 15 years old now and she has reached the age at which the custody of men is needed. I agree with my colleague that Ziyād had beaten his daughter in public twice but he did not exceed the limits of disciplining children. The beating did not cause anguish. This is part of his role as a father. He wants to continue his duty of supervising his daughters, and to provide them with the best Islamic education. If her hair became visible during the quarrel, that happened accidentally, of course. Therefore, I request the court to implement the law in this regard and allow my client to get his daughters back.'

The case was heard by qā $\bar{d}$ al-Karmī. After hearing testimony over several sessions, alKarmī made up his mind: 'In view of article 386 of the Personal Status Law, the father is not eligible for custody over his daughter Samāhir. ${ }^{6}$ This decision may be submitted to the Court of Appeal. Custody is something that cannot be divided. Therefore, the father who is ineligible for custodianship over Samāhir is also ineligible for custodianship over her sister for the same reason.'

The matter did not end there because the father appealed to the higher court. The Court of Appeal did not accept qädì al-Karmì's judgment and sent the case to qädì Muhammad al-

Ansārī, who ordered Adāla to hand over Samāhir and Ilhām to their father: 'The daughters are of the age to be placed in men's custody $\ldots$ in accordance with articles 16, 18, 38, 39, 46, 48, 81 and 83 of the Code of Islamic Jurisprudence and article 391 of the Family Law, we have decided to order the mother Adāla to deliver Samāhir and Ilhām back to their father. We took into consideration the following facts: (1) The father's right of custody should not be jeopardized by the fact that he did not file a legal case earlier. (2) The witnesses have testified that the father is an ordinary, reliable and protective Muslim. Therefore, he is eligible to take his daughters under his supervision. (3) The testimony concerning Ziyād's beating of his daughter seems to have been magnified by some witnesses. (4) The most important thing is that his daughters have become mature (bäligh) and need the guardianship of men. Therefore, we give the father the right to take them back and we oblige the mother to deliver them to their father so that they can be taken care of as stipulated by the sharia.'

Khālid al-Tayyib, the daughters' lawyer, did not accept the new judgment. He had to devise another strategy to allow the girls to stay with their mother. He exploited all the legally available routes. One semi-formal option was an intervention by the deputy qàdi al-qudàh, so the lawyer arranged a meeting with him for Adāla. She and six of her children went to the deputy

\footnotetext{
${ }^{6}$ Article 386 (of the Book of Personal Status Rulings According to the School of Abū Hanīfa compiled by Qadrī Pāshā of 1875) states that if there is no legitimate guardian, or if the guardian is insane, dissolute, or unsafe, the child should not be transferred to him. The article also stipulates that, in such cases, girls should be transferred to their (muhram) male kin; that is grandfathers, uncles in the mother's line, and so on. $Q \bar{a} d \bar{l}$ al-Karmī, however, did not pronounce his ruling in accordance with this article. He settled the case in a way that would serve the interests of the girls and their mother.
} 
qàdì al-qudāb's office accompanied by Khālid al-Tayyib. 'The lawyer explained the case to the deputy qädì al-qudāh and made it clear that Ziyād was not seeking custody because of his willingness to care for his daughters; rather, his action was intended to put pressure on the mother to forego her demand for nafaqa. The deputy qädi al-qudāh sympathized with the mother and gave her the following advice:

I will order the court to reassess the case despite the decision of the Court of Appeal. The case will be heard by al-Karmī because, obviously, he is very familiar with it and his initial judgment was more in line with the shari' $a$ than the second one. You have to give your former husband the impression that you are willing to give up your children. When the hearing takes place, let your daughters ask him to take them all. On our part, we will put pressure on him to take all the children. He has remarried and his wife is unlikely to accept your 'army', fearing they would ruin her house and life, especially your youngest 'monsters'. They are not hers. The best thing we can do is to send them to her and give her an unpleasant surprise. She has to get mad. This depends on your children's behavior. Once they are there, they should be noisy, break plates, play football indoors, and switch the TV on and off all the time. In sum, they have to drive the wife crazy. Your children will return to you the next day.

On the day of the hearing, the father and daughters were present in court. The girls stood in front of qädi al-Karmī and played the role assigned to them by the deputy qädi al-qudāh: "We do not want to leave our brothers and sisters. Our father should not choose whom to take and whom to leave. You should help us to continue living together. We would love to go to our father's place but he should take us all. We will not go alone, either he takes us all or leaves us all.' Qádi al-Karmì turned to the father and told him, 'Now you have an excellent opportunity to take all your children to live with you. Your ex-wife does not object to that and the children want to live with you, so what is your decision?' The father had no option but to tell the qàdi, 'Yes, of course, they are my children and I will take them all.' Adāla sent all her children to their father's house the same day. There, they followed the instructions of the deputy qädi al-qudāh. Within an hour of their arrival, they were returned to their mother's house.

The deputy qādì al-qudāh also informed Adāla that it was unfair to deduct $60 \%$ of Ziyād's salary. She had to compromise in order to keep her children with her. She decided that it would be enough for her to receive JD 100 instead of JD 250. That was not the best deal, but she has to accept it as part of the comprehensive bargain.

\section{Synthesis}

The law operates on the supposition that both agnatic and maternal kin act in good faith with equal degrees of responsibility and decency. Yet, when examining its application, we find that it is more dependent upon people's circumstances and motives than of any intentions. In practice, the agnates generally try to use their legal precedence to further their personal interests. While claiming their rights to guardianship, what is significant in the agnates' behavior is their attempt to manipulate the law, both by keeping the rights assigned to them and by evading the duties attached to these rights. In particular, family law ensures the custody right of agnates and links it with their financial duties. However, in practice, agnates always adjust this provision to meet their objectives, which often do not match the intentions of the law. It is in this ambivalent area between fixity (of the text) and indeterminacy (of people's behavior) that men manipulate their fixed rights. Agnates misuse the advantages assigned to them through the law's gendered

\footnotetext{
${ }^{7}$ There is an important difference between the conduct of the deputy $q \bar{a} d \bar{l}$ al-qudāh and other PA officials: despite his ministerial rank in the PA hierarchy, the deputy $q \bar{a} d \bar{l}$ al-qudāh office is known to be easy to approach.
} 
distribution of rights and instrumentalize children, either to gain benefit or to minimize their financial losses.

Mothers, who are severely disadvantaged by the text, struggle to correct its asymmetry by holding men (fathers or agnates) responsible for their legal duties. They do this by using the means at their disposal. There is no normative vacuum between text and practice (Griffiths 1992); rather, a social space exists, and it is within this space that people generate and manipulate it. The fate of children's hadana is a result of negotiation and social struggle between the actors, including the judges, who have to be accountable to a variety of ethical, social, political, and occupational domains.

Lawyers, for their part, do not limit themselves to the letter of the law; they also blend idioms from the shari $a$ with cultural norms to be used as reference points while presenting their cases. That was the situation in the case of Adāla, with the lawyer employing religious and cultural norms to disqualify the father's claim of custody over his daughter. Since the headscarf is considered an essential aspect of women's public appearance, the lawyer argued that the father would not be a suitable custodian because he had torn the headscarf from his daughter's head, exposing her hair to public gaze.

The central objective of judges is to provide people with what they view as 'justice' (baqq). Judges, as argued, have several references at their disposal. Codified law is the written reference, while 'legal concepts' are unwritten. This study has identified concepts such as public welfare (maslaha), equity (istibsän), protecting the weak, customarily acceptable practices, and others which serve this purpose. These concepts are flexible, permeable, ambiguous, and unspecific. Judges, using diverse strategies, exploit the characteristics of these concepts to arrive at a correct and 'just' (baqq) solution. The legal concepts used by judges do not operate in a vacuum; they are part of the historical, economic, social, and political context of their operation. They are also permeated by the interests, values, and perceptions of judges as well as of people. As demonstrated, the judges view themselves and are viewed (by litigants) as representing not only a legal institution but also moral and religious authority. In the case of Adāla, they plot with a female litigant to devise a strategy to keep her children. In this case, the judge not only reinterpreted the law, but disregarded its relevance.

The qādì al-qudāh's strategic advice to Adāla is insightful with regard to the degree of the judges' embeddedness in the social fabric of Gaza. He is not mere implementer of the law; rather he exercises a degree of discretion informed by his self-perception as members of his community. Moreover, judges in general are well informed about 'who is who' in the community and have strong contacts with the community leaders and other influential social and political figures. Their decisions depend not only on the history of cases filed, but more importantly, on the potential consequences of their judgments on the individual litigants and the larger community behind them (Rosen 1989). The qädì al-qudäh's ability to predict the second wife's response and his willingness to provide 'justice' to the children enabled Adāla to keep her children.

The criterion of litigants' 'rightness' or 'wrongness' depends on the context within which the dispute takes place. The qàdi assesses the wrongdoing of a litigant against that which is defined by society as normal behavior. Interestingly, the same trend, that is, placing the transgression of social norms within the framework of socially accepted behavior, can also be observed among litigants. When they communicate with the qädi, they often refer to his moral and religious authority instead of his legal position. Women frequently address the qādi as the father of Muslims, the protector of God's worshippers, and so forth; and men do the same. Even when protesting the qädis interventions, they frame their objections in religious and moral idioms. There is a dialectic relation between the ethical requirements of shar ${ }^{-} a$ in which the judges are well-trained, and the legally sanctioned principles of gender asymmetry. When judges find that strict adherence to the written code would lead to an unjust outcome, they strive to interpret the law in a way that makes it more in harmonious with its objectives. The case of Adāla is also relevant in discussing issues related to women's agency. The concept of 'agency' is a powerful 
analytical tool for understanding and theorizing on how women subvert or resist their domination; and whether, how, and in which ways women contribute to the continuation of their own subordination. If agency means choices to be made as a means of realizing one's own wellbeing, does this imply that the direction of women's action should be 'fixed a priori' (Mahmood 2001: 212)? In other words, when a woman decides, for example, to present herself as helpless and capitalizes on the judge's empathy and his notion of protection, does such an action imply that she is contributing in some way toward reinforcing her state of subjection? Acknowledging women's agency entails taking into account the specific historical and cultural context that creates the conditions within which women operate and make their choices. This practical notion of agency refers to their ability to cultivate their capabilities in order to attain their goals, despite (or perhaps due to) the injustices they have experienced.

The action of filing a suit, regardless of its outcome, is an empowering step. This was shown in the case of Adāla, who used the action of going to court as an integral part of her strategy and not just as a procedural action. Astonishingly, the judges, the very figures whose function is assumed to be to safeguard the law, supply women with the means of overcoming their difficulties and thus assist them in strengthening their bargaining position vis-à-vis the children's guardians. Women, moreover, carefully choose which norms to invoke and in what forum to do so.

The most striking feature of the observed case is that nothing was registered in the court record except a brief statement outlining the final ruling. In Adāla's case, the qādì al-qudāh's strategy was communicated behind closed doors. Under the circumstances, the only way to trace the daily 'ijtihad' (independent reasoning) of judges is to observe it on the spot. The protection of the child's best interests stood in conflict with codified law, and therefore the qädi had to ignore the latter in order to carry out his duty as the provider of 'justice'. Some might argue that this behavior is expected of those who have authority in the legal system. Yet the question remains as to what would be the impact of recording these interventions on the development of Islamic legal theory. If the legal system acknowledged such interventions and required the judge to put them down in writing, then the extent to which daily 'jurisprudence' contributes to Islamic legal theory would be greater.

This takes us to another point related to the debate on codification and ijtibäd. The process of codification produced a written legal corpus that is poorer than those of the four madhähib (schools of Islamic jurisprudence), in which contradictions are a built-in aspect of jurisprudence and thus allow for the adaptation of the legal judgments to the existing needs of society. The movement towards codification has confronted judges with an irresolvable problem: if, on the one hand, they apply the codified law as is, they inevitably injure both litigants and the moral principles of the shari' $a$ through 'unjust' judgments. If, on the other hand, they go beyond the scope of the codified statutes, they can be held responsible for violating the law. To resolve this dilemma, judges rely on orality. Most of their actions, reactions, interventions and 'violations' of codified law are, understandably, not recorded anywhere. The fact that they have the authority to dictate the written record allows them to decide on the exclusion or inclusion of certain material; oral negotiations, the devices of certain judgments, out-of-court solutions, and in-court propositions appear nowhere in the court record. Thus, no one can trace the judges' exercise of ijtihäd. In view of this reality, the argument put forward by Tucker (1998), namely that the codified law has come to affect the subjectivity of judges, holds true as long as the evidence studied is confined to written texts or archival material. Codification forces jurisprudence to resort to orality, which means that there is no way to reconstitute the entire picture unless the researcher adopts an appropriate methodology based on the observation and recording of the daily practice of ijtihäd. Another consequence of orality is the judges' inability to rely on precedents. The lack of written precedents makes every case 'new' and to be dealt with not on the basis of what has been accumulated through court history, but on the basis of the accumulated experience of the individual qädi alone. Contemporary ijtibäd is obscured by the 
recourse to orality. Innovations are covered up and changes in the system concealed. Every qädi, therefore, is a universe unto itself, whose judgments are made subjectively and transmitted orally. Ra'y (subjective reasoning), which is one of the foundations of $\ddot{j} t i b \bar{a} d$, is obscured through orality and thus no legacy (turath) is allowed to accumulate. This leads to stagnation of the text on the one hand, and proliferation of oral ijtiha d on the other.

\section{Conclusion}

This paper has reviewed how the gender-based double standard of hadana is articulated in the text. However, when we turn to the practice we attain greater insight into how the law is socially constructed. This requires considering people's counter-consensual actions, for law is not transmitted from legal authorities to litigants by 'cables'. Communication between the legal authorities and citizens is rarely unmediated (Griffiths 1992). How, the paper inquired, did the actors in the court perceive the law? What sorts of accommodations or modifications were made by actors in the court, be they decision-makers or litigants? In which areas did adjustment or non-adjustment occur, and why? Which ambivalences in codified law allowed people to adjust situationally? How do gender, social status, and class play out, together or separately, in the process of adjustment? Which historical or temporal indeterminacies allowed and still allow people to adjust the law? In particular, the paper, while comparing the relevant text with its practice, did not seek to examine whether family law is effectively applied or obeyed; rather, the main aim was to investigate how it worked sociologically. It was in this examination that the law appeared less influential than assumed by social engineering theorists. ${ }^{8}$ Moreover, the people's conduct not only suggests a difference between text and practice but also directs our attention to the quality of this difference: the text is often more conservative than the practice. This confirms the argument put forward by Dwyer (1990), which emphasizes the importance of reading the text through the eyes of the people rather than through an ideological presentation of Islamic law. Rules, as Moore (2005) points out, do not always rule. The sociology of law acknowledges that law operates in a culturally specific domain and within a context of social relations full of inconsistencies, ambiguities, and discontinuities. This approach has indeed been useful in Gaza. Recognizing the temporality of people's circumstances is essential in light of the indeterminacy that exists as a pervasive reality for people who endure enormous instability under the brutal and continuous Israeli occupation. The ethnography on the judicial reasoning in this particular corner of Palestine may prove useful, to the extent that it illustrates the capacity of judges to create a legal framework that can encompass multiple sources of law, amid litigants' shifting strategies. The disparity between the discretion of the judges and the purported binding code raises a double question: In whose interest does the judge rule in family law cases? What does it mean to adhere to the notion of rule of law when the judge decides as he sees fit? The answer - as the case of Adāla indicates - is that the judges' discretion is able to serve the best interests of the weaker party and the rule of law is once again a notion that requires careful revision.

\section{Bibliography}

Books and Articles

Anleu, S. L. R. (2000) Law and Social Change. London and New Delhi: Sage.

Botiveau, B. (1997) Al-sharǐa al-islämiyya wa al-qānūn fi al-mujtama 'ät al-

\footnotetext{
${ }^{8}$ Anleu (2000: 2) argues that 'during the Twentieth Century, there is increasing reliance on the law as a route, or resource, to implement desired social change. In part this reflects the aspiration for the welfare state and its social reform agenda, which rely on the statutory implementation and bureaucratic administration of social programmes.' However, recent socio-legal commentators have started questioning the meaning of legal change, especially with growing inequalities in societies (Frohmann and Mertz 1994: 829). The main point is that legislation cannot change society alone; change is greatly influenced by cultural factors such as the institution of family, kinship, descent system, religion, and other socio-economic variables (Singh 1989).
} 
'arabiyya. [The Islamic Shari'a and Law in Arab Societies]. Cairo: Sienna.

Chanock, M. (2000) 'Introduction' to the $2^{\text {nd }}$ edition of S.F. Moore Law as Process: $A n$ Anthropological Approach (1978), Hamburg: LIT VERLAG and James Currey.

Dwyer, D.H. (1990) 'Law and Islam in the Middle East: An Introduction', in D.H. Dwyer (ed.) Law and Islam in the Middle East, pp. 1-15. New York: Bergin \& Garvey.

Esposito, J. (1982) Women in Muslim Family Law. New York: Syracuse University Press.

Frohmann, L. and E. Mertz (1994) 'Legal Reform and Social Construction: Violence, Gender and the Law', Law and Social Inquiry 19: 829-51.

Gerber, H. (1994) State, Society, and Law in Islam: Ottoman Law in Comparative Perspective. Albany: State University of New York.

Gluckman, M. (1955) The Judicial Process Among the Barotse of Northern Rhodesia. Manchester: Manchester University Press.

Griffiths, J. (1992) 'Legal Pluralism and the Social Working of Law', in B. Brouwer, T. Hol, Arend Soeteman and A. de Wild (eds.) Coherence and Conflict in Law: Proceedings of the $3^{\text {rd }}$ Benelux-Scandinavian Symposium in Legal Theory, pp. 151-76. Amsterdam and Deventer: Kluwer Law and Taxation Publisher.

Hallaq, W. (1984) 'Was the Gate of Ijtihad Closed?', International Journal of Middle East Studies 16: 341. Also in I. Edge (1996) (ed.) Islamic Law and Legal Theory: The International Library of Essays in Law \& Legal Theory, pp. 287-325. Adershot: Dartmouth.

Layish, A. (1975) Women and Islamic Law in a Non-Muslim State. Jerusalem: Tel Aviv University. Shiloah Center for Middle Eastern Studies.

Mahmood, S. (2001) 'Feminist Theory, Embodiment, and the Docile Agent: Some Reflections on the Egyptian Islamic Revival', Cultural Anthropology 16(2): 202-36.

Moore, S.F. (1973) 'Law and Social Change: The Semi-Autonomous Social Field as an Appropriate Subject of Study', Law and Society Review (7): 719-46.

Moore, S.F. (1978) Law as Process: An Anthropological Approach. London: Routledge \& Kegan Paul.

Moore, S.F. (2000) Law as Process: An Anthropological Approach (1978): New Introduction by Martin Chanock, $2^{\text {nd }}$ edition. Hamburg: LIT VERLAG and James Currey.

Moore, S. F (2005) 'Certainties Undone: Fifty Turbulent Years of Legal Anthropology, 19491999', in S. F. Moore (ed.) Law and Anthropology: A reader, pp 347-67. Malden, Oxford and Victoria: Blackwell.

Moors, A. (1995) Women, Property and Islam: Palestinian Experiences 1920-1990. Cambridge: Cambridge University Press.

Pospisil, L. (1971) Anthropology of Law: A Comparative Theory. New York: Harper \& Row.

Rosen, L. (1989) The Anthropology of Justice: Law as Culture in Islamic Society. Cambridge: Cambridge University Press.

Samara, M. (1987) Abkäm wa äthär al-zawjizya: sharh muqäran li-qānün al-ahwäl al-shakhsiyya (Rules and Consequences of Marriage: Comparative Commentary on the Law of Personal Status). Jerusalem (no publisher).

Singh, I. P. (1989) Women, Law and Social Change in India. London: Sangam Books.

Shehada, N. (2005) Justice without Drama, PhD Dissertation, The Hague. Shaker.

Welchman, L. (1999) Islamic Family Law: Text and Practice in Palestine. Jerusalem: WCLAC.

Welchman, L. (2000) Beyond the Code: Muslim Family Law and the Shar'i Judiciary in the Palestinian West Bank. The Hague: Kluwer Law International.

Zahraa, M. and N.A. Malek (1998) 'The Concept of Custody in Islamic Law, Arab Law Quarterly 13(2): 155-77.

\section{Legislation}

\section{Laws applied in the shari' a courts of the Gaza Strip}

BPSR (1875): 'Kitāb al-abkām al-shar'iyya fi al-ahwāl al-shakhsiyya 'alā madhhab al-imäm Abü Hanifa' (The Book of Personal Status Rulings According to the School of Abū Hanifa) compiled by Muhammad Qadrii Pāshā, in Dahdūh et al. 1996, pp. 2-107. 
LFR (1954): 'Qānūn huqūq al- 'â'ila' (Law of Family Rights) regulated by the Egyptian Governor General of Gaza Strip by order number 303 (special official Gazette 22/5/1965), in Dahdūh et al., 1996, pp. 108-22. 